"The importance that customers place on service attributes of sale personal in the retail sector"

AUTHORS Louise van Scheers

ARTICLE INFO

DOI

RELEASED ON

JOURNAL

FOUNDER
Louise van Scheers (2016). The importance that customers place on service attributes of sale personal in the retail sector. Investment Management and Financial Innovations, 13(3-1), 222-227. doi:10.21511/imfi.13(3-1).2016.08 http://dx.doi.org/10.21511/imfi.13(3-1).2016.08

Friday, 23 September 2016

"Investment Management and Financial Innovations"

LLC "Consulting Publishing Company "Business Perspectives"

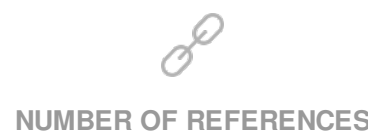

0

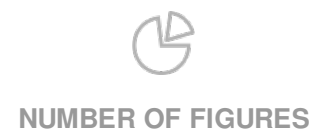

0

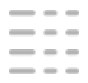

NUMBER OF TABLES

0

(C) The author(s) 2023. This publication is an open access article. 


\title{
The importance that customers place on service attributes of sale personal in the retail sector
}

\begin{abstract}
When examining retail patronage, customer satisfaction must also be considered. Secondary resources (American Marketing Association, 2007; Berman, 2011; Berry, 2008; Chang, 2006, p. 209; Helgesen \& Nesset, 2007, p. 129, Kong and Jogaratnam, 2007, p. 279) observed that customer satisfaction is the degree to which customer's expectations agree with the actual performance of the product and/or service
\end{abstract}

South African consumers situated in Gauteng consider a sales person's product knowledge as the most important attribute when making purchasing decisions. American consumers, in contrast, consider sales person respect as the most important attribute when making purchasing decisions. The implications for marketers and sales managers are that marketers and sales managers must provide adequate training for their sales personnel in order for them to treat customers in such a way to obtain their loyalty.

The quality of the products sold at the retailer does not form part of the trade off options that customers are presented with.

Keywords: retail store customer, prices compared to competitors, salesperson product knowledge, salesperson responsiveness, South African retail consumers.

JEL Classification: L81, M31.

\section{Introduction}

The ever changing retail environment creates several challenges for retailers, such as emphasizing quality, value, customer satisfaction, and customer retention (Reichheld, 2006; Siu and Cheung, 2011). Since competition between retailers have increased due to the increase in shopping centres and the steep rise in product prises, retailers are forced to provide a level of service that would make customers return to their stores instead of going to competitors' stores. This study examines the importance that customers place on service attributes of the sales personnel in the retail sector. This is a retail patronage intention study conducted in Gauteng, South Africa amongst individuals who had purchased a cell phone to the value of at least R2 500 or more. As the South African retail markets move toward saturation and consumers take advantage of price competition, understanding the role of price as a driver of retail selection. Low prices, in the form of either price promotions or general price levels, can create store traffic and increase category sales, but the extent to which consumers use price as an indicator of quality depends on the information available to the consumer.

The study, furthermore, examines the impact of selected salesperson service attributes and levels on consumer patronage intentions in a consumer electronics store setting. Some studies found that various aspects of convenience can be influential on customers satisfaction with the service received.

(C) Louise van Scheers, 2016.

Louise van Scheers, Professor, School of Business Management, University of South Africa, South Africa.
Two of these are a customer's reduced mental effort and perceived waiting time (Darian \& Cohen, 2005; Darian, Tucci \& Wiman, 2001).

Therefore, the following hypotheses were formulated:

$\mathrm{H}_{1 \mathrm{a}}$ : The price of a product is negatively related to retail patronage.

$\mathrm{H}_{0 \mathrm{a}}$ : There is no correlation between the price of a product and retail patronage.

$\mathrm{H}_{2 \mathrm{a}}$ : There is a positive correlation between salesperson's product knowledge and retail patronage.

$\mathrm{H}_{0 \mathrm{a}}$ : There is no correlation between salesperson's product knowledge and retail patronage.

\section{Literature review}

\section{Customer satisfaction and service quality}

Customer satisfaction is the degree to which customer's expectations agree with the actual performance of the product and/or service (American Marketing Association, 2007; Berman, 2011; Berry, 2008; Chang, 2006, p. 209; Helgesen \& Nesset, 2007, p. 129 and Kong and Jogaratnam, 2007, p. 279). Customers form service quality expectations based upon previous retail store service received; they are further influenced by information provided by people that surround them and whose advice they would follow (American Marketing Association, 2007; Gilbert and Veloutsou, 2006, p. 298). Darian at al. (2001) observe that dissatisfied customers generally do not enter complaints at the store, but rather complain about the service received to friends, family and other people in their influential group. Furthermore, they pointed out that dissatisfied customers tend to either switch to 
another store or spend less time at the store that do not provide the expected service or price that the customer is willing to pay. In order to critically and successfully determine customers' service quality, retailers must determine the factors that customers use when they evaluate the actual service quality (Sureshchandar, Chandrasekharan and Anantharaman, 2002, p. 368; Yap and Sweeney, 2007, p. 142).

\section{Product price and value}

Value can be defined as a subjective process whereby the consumer weighs benefits received against sacrifices incurred, where the benefits include the entire service process, emotional and social aspects (Roig, Garcia, Tena and Monzonis, 2006 , p. 270). The strong relationship between consumers' perceived value and their intention to purchase, as well as the effect of perceived value on word-of-mouth communications have been demonstrated in previous literature (Alexandris, Dimitiradis \& Markata, 2012, p. 227).

Secondary research (Moore \& Carpenter, 2006, p. 266), suggests that retail customers perceive price in both positive and negative cues that ultimately influence their purchasing behavior. When price is perceived as a positive cue, it signals quality, prestige, or status to the customer. When it is perceived as a negative cue, it is perceived as an economic sacrifice. In both positive and negative respects, perceptions of price operate as marketplace cues that aid the customers in their purchase decision making process. Moore and Carpenter (2006, p. 268) identified that customers who are highly price conscious usually visit low priced stores, mass discounters, and value priced retailers, as they tend to be more sensitive towards the prices that a retailer charge for a product. In this study, the researchers considered seven different retail situations, but were not product specific. Thus, after considering the literature, the following hypothesis was decided on using cell phones as a specific product category:

\section{$\mathrm{H}_{1 \mathrm{a}}$ : The price of a product is negatively related to retail patronage.}

\section{Salespeople performance attributes}

In a retail store setting, the interaction between sales personnel and customers constitutes a unique and important dimension of performance. This is due to the fact that customers form an image about the store and its service quality based upon the service provided by the sales personnel. As such, it stands to have a strong impact on retail customer satisfaction (Babakus, Bienstock and Van Scotter, 2004, pp. 727-723). The interaction between the retail store's sales personnel and the customer forms part of the personal interaction dimension of a service, and the price levels of the retail store form part of the reliability dimension of the service (Siu \& Cheung, 2001, p. 89). The personal interaction dimension of a service can include whether personnel are courteous, helpful, and knowledgeable and whether they inspire confidence and trust from the customer. The reliability dimension include whether the retailer keep promises made to customers through its various communication methods (Siu \& Cheung, 2001, p. 89). Therefore, knowledge about customer perceptions regarding the critical dimensions of salesperson performance is crucial if the retail firm is to provide quality, value and satisfaction (Robledo, 2001, p. 26). Despite this, previous studies have shown 19\% of salespeople receive no training, not even introductory training; resulting in sales personnel not considering the customer when delivering a service (Pettijohn and Pettijohn, 1994, p. 21). For the purpose of this study, the focus will be placed on two of the salesperson attributes that contribute to the consumer decision making. This is, namely, salesperson's product knowledge and salesperson's responsiveness. These concepts will now be discussed in more detail.

\section{Salesperson product knowledge}

The level of product knowledge illustrated by a salesperson is believed to influence retail patronage. A study done by Discount Store News in 1995 showed that there is an increased demand from consumers for more knowledgeable salespeople. The more knowledgeable the salesperson, the more likely the consumer will be to return to the store for similar purchases, as he/she knows that the sale team will be able to assist them in making the right choice. This gives the consumer peace of mind when purchasing a product from the particular store. Therefore, the second hypothesis that will be tested in this study is as follows:

$\mathrm{H}_{2 \mathrm{a}}$ : There is a positive correlation between salesperson's product knowledge and retail patronage.

\section{Salesperson responsiveness}

Another factor that is believed to have an influence on retail patronage is salesperson responsiveness. Tucci (2001, p. 206) highlighted a study done by Speer (1995) that identified that salespeople who are overly talkative or distant are viewed less favorably by consumers. By doing proper training, a salesperson can see when a consumer needs assistance. The more approachable and open a salesperson is towards the consumer, the more likely the consumer will be to return to the store where he/she made the first purchase. From the above argument, the following hypothesis was developed and will be tested in this study: 
$\mathrm{H}_{3 \mathrm{a}}$ : There is a positive relationship between salesperson responsiveness and retail patronage.

Taking the above literature discussion into account, the following section will discuss the methodology used in the study.

\section{Methodology}

100 consumers in Gauteng who purchased a cell phone within the previous three months, to a value of at least R2 500, were asked to evaluate their preferences with regard to service levels at retail stores. The service levels were:

- Prices compared to competitors (prices about R120 below competitors; prices about the same as competitors; prices about R120 above competitors).

- Salesperson knowledge (poor product knowledge; fairly good product knowledge; excellent product knowledge).

- Salespersons responsiveness (not responsive uses hard sell approach; fairly responsive to customers' needs; very responsive to customers' needs).

The South African study used conjoint analysis as the basis to investigate customers' preferences for customer service levels and features. Most people, when asked to rate how important customer service attributes are would indicate that all or most are important, as will be seen with derived importance of the attributes. With conjoint analysis, individuals are presented with different levels within the attributes, and this approach, therefore, combines realistic trade-offs when individuals indicate preferences. Respondents within LSM (Living Standards Measure) 6-10 segments were approached with the objective of finding 100 who had purchased a cell phone within the last three months. All interviews were conducted on a personal basis.

\section{Testing of two conjoint tables}

The final research output confirms that the results show specific differences in the asymmetrical design vs. the symmetrical design. The summary of findings compares the output of the symmetrical design and it was found that the output of the symmetrical design is a more valid representation of customers trade-off's when making a purchasing decision.

\section{Research results}

Figure 1 indicates retail customers' perception about the three attributes measured, namely, price level, salesperson product knowledge, and salesperson responsiveness.

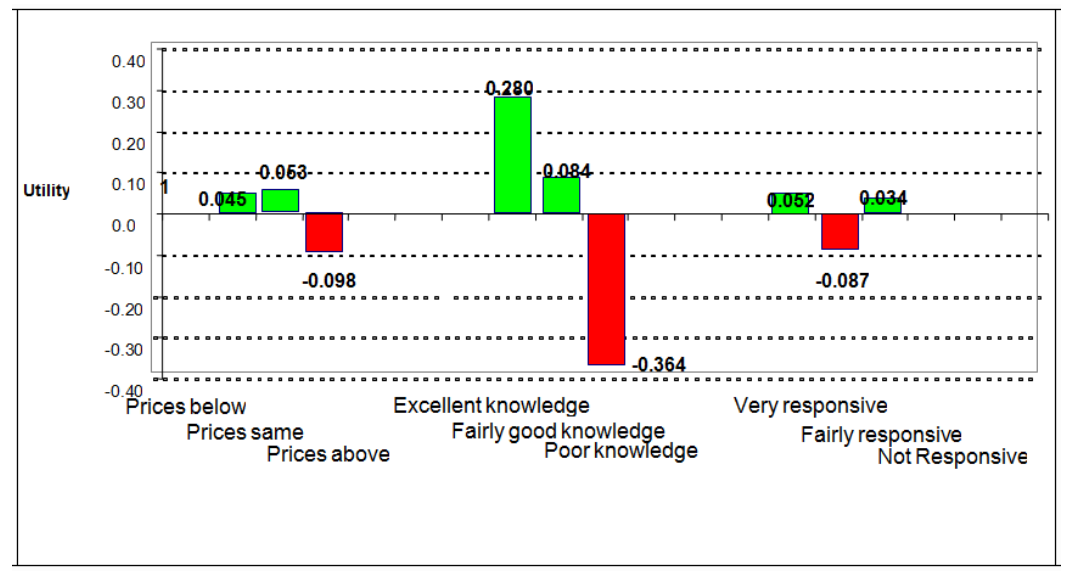

Fig. 1. South African consumer preferences for retail salesperson abilities and price levels (LSM 6-10)

In Figure 1, it is evident that South African consumers (in Gauteng) purchasing electronic goods (such as cell phones) value excellent product knowledge in a salesperson at a much higher level than the salesperson/retailer offering lower or similar prices to competitors. In fact, prices below competitors emerged with the third lowest positive utility indicating that pricing, compared to other service attributes, contributes proportionately much less to a successful sale than product knowledge and responsiveness do. The following hypothesis was formulated:

$\mathrm{H}_{1 \mathrm{a}}$ : The price of a product is negatively related to retail patronage. The results indicated that $\mathrm{H}_{1 \mathrm{a}}$ can be neither accepted nor rejected and, therefore, the null hypothesis will be accepted, there is no relation between the price of a product and retail patronage.

The following hypothesis was formulated:

$\mathrm{H}_{2 \mathrm{a}}$ : There is a positive correlation between salesperson's product knowledge and retail patronage. It is also apparent in Figure 1 that poor product knowledge in a salesperson/retailer emerged with the lowest negative utility. This implies that lack of product knowledge in a salesperson/retailer will negatively impact on the purchase of electronic goods from such a retailer or salesperson. Therefore, $\mathrm{H}_{2 \mathrm{a}}$ can be accepted, there is, in fact, a positive relationship between a salesperson's product knowledge and the retail patronage. 
The following hypothesis was formulated:

\section{$\mathrm{H}_{3 \mathrm{a}}$ : There is a positive relationship between} salesperson responsiveness and retail patronage.

It is also apparent in Figure 1 that poor responsiveness in a salesperson/retailer is a factor which has an influence on retail patronage. This implies that poor salespersons responsiveness will negatively impact on the purchase of electronic goods from such a retailer or salesperson. Therefore, $\mathrm{H}_{3 \mathrm{a}}$ can be accepted, there is, in fact, a positive relationship between a salesperson's product knowledge and the retail patronage.

Figure 2 shows the linear relationship between retail consumers' perceptions about the different levels of retail store prices.

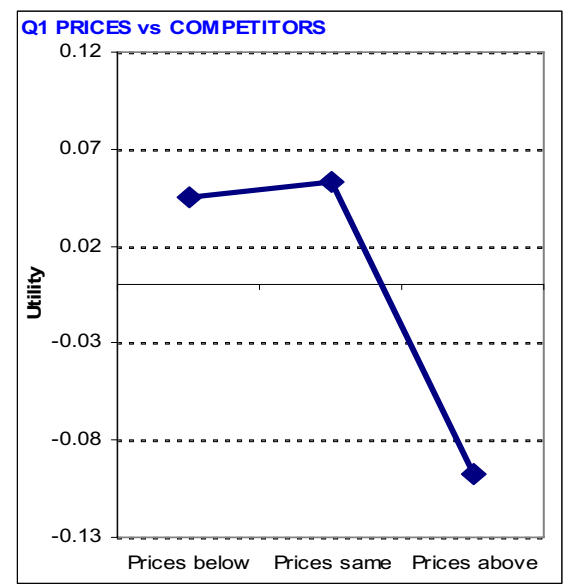

Fig. 2. Consumer perceptions about retail store prices

Figure 2 indicates that it makes little difference whether prices are about the same as competitors or below that of competitors, but prices above competitors (in and of itself) are viewed negatively by store consumers.

Figure 3 shows the linear relationship between retail consumers' perceptions about salesperson product knowledge.

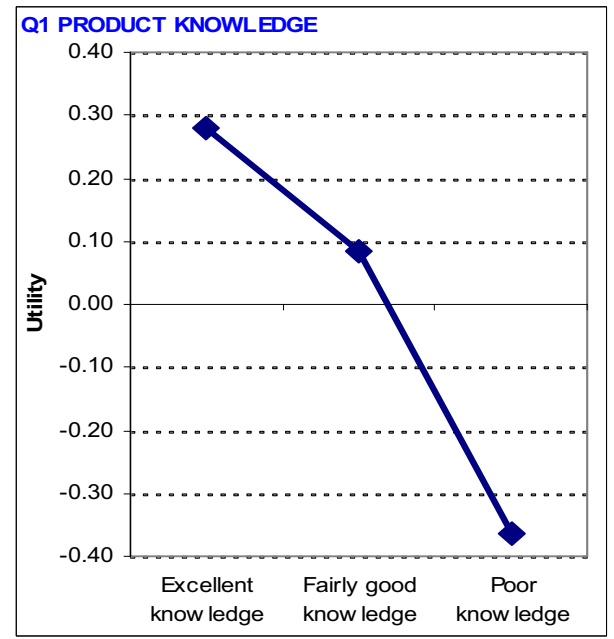

Fig. 3. Consumer perceptions about salesperson product knowledge
In Figure 3, product knowledge has a reasonably linear relationship, although excellent product knowledge has three times the utility than fair product knowledge. Poor product knowledge is viewed extremely negatively. This shows that consumers are much less likely to purchase from an outlet where there is poor product knowledge.

The following hypothesis was formulated:

$\mathrm{H}_{2 \mathrm{a}}$ : There is a positive correlation between salesperson's product knowledge and retail patronage.

The $\mathrm{H}_{2 \mathrm{a}}$ was accepted and results show that there is a linear relationship between retail consumers' perceptions about salesperson responsiveness.

\section{Managerial implications}

The initial interpretation of the results show that all variables are regarded as important by customers when making a purchase of cell phone of at least R2 500. The above variables can be regarded as minimum standards or entry level requirements for any retail outlet, if managed properly. Compared to the restaurant industry, for example, a clean restaurant serving fresh food will also be two variables that will be non-negotiable and be regarded as entry level requirements. However, using conjoint analysis to determine a trade off that customers will make when choosing a retail outlet to buy electronic goods does highlight preference, as well as the extend of these preferences of variables that may on face level be regarded as equal in importance.

\section{Prices compared to competitors}

It will be beneficial for sales staff to know the prices of competitors and be trained with answers why a cheaper or more expensive price adds more value compared to competitors, either through warranties, after sales service or the other variables.

\section{Sales person product knowledge}

This variable is regarded as the most important variable by Gauteng consumers which can be a function of risk, techno phobia or peer pressure. It shows that consumers in South Africa (Gauteng) in general may not be as knowledgeable about electronic goods or do not always have the means (such as Internet access) to gather information to make informed purchasing decisions. For many consumers, a price tag of at least R1000 does also offer a degree of risk and reinforcement of the purchasing decision through proper product knowledge and recommendation of a product (brand) to satisfy each individual consumer's specific needs is important when training sales people.

Although technical terminology may be of importance to use with certain customers that also 
have above average of electronic goods, explanation of product features in everyday language will engender trust amongst the average customers buying an electronic good for the first time.

\section{Sales person responsiveness}

Responsiveness is a function of a specific situation and may differ from customer to customer. The golden rule may at least be for sales staff to offer their advice if so requested by the customer, as well as what the specifics of the advice will be, such as:

- "I can give you a range of brands and prices that the store offer".

- "I can outline the price range of competitors".

- "I can explain the basic product features of the different brands and where they are manufactured".

- "If you tell me what your main purpose and use of the product is going to be, I can offer you a number of products to choose from to best serve your needs".

The conjoint trade off shows that responsiveness should not be store policy, but should rather be one that serves the needs of the customers. Being visible and available when needed will likely be the first step that management should put in place to meet the different responsiveness needs that consumers might have. Consumers want to see the salesperson, but only want their advice when needed.

\section{Conclusion}

This study was inspired by a similar study conducted in the States. The study explored the trade offs made by consumers during their purchasing decision of electronic goods. It is evident that product knowledge will have to form an important part of the literature review, as this is regarded as the most important attribute for South African consumers.

The results of this study can be summarized as follows:

- $\mathrm{H}_{1 \mathrm{a}}$ can be neither accepted nor rejected and, therefore, the null hypothesis will be accepted, there is no relation between the price of a product and retail patronage.

- $\mathrm{H}_{2 \mathrm{a}}$ was accepted and results show that there is a linear relationship between retail consumers' perceptions about salesperson responsiveness.

- $\mathrm{H}_{3 \mathrm{a}}$ can be accepted, there is a positive relationship between a salesperson's product knowledge and the retail patronage.

South African consumers will find salesperson responsiveness, especially product knowledge important; consumers want to see the salesperson, but only want their advice when needed; and consumers compare prices of competitors. The South African consumer considered 'proper product knowledge and recommendation of a product (brand) to satisfy each individual consumer's specific needs as the most important factor. The conclusion can be made that may be the South African consumer is not that knowledgeable about product feature. This is may be due to the culture and technology level of the country.

\section{References}

1. Alexandris, K., Dimitiradis, N. and Markata, D. (2012). Can perceptions of service quality predict behavioural intentions? An exploratory study in the hotel sector in Greece, Managing Service Quality [online], 12(4), pp. 224231. Available from: http://www.emeraldinsight.com/Insight/viewPDF.jsp?Filename=html/Output/Published/ EmeraldFullTextArticle/Pdf/1080120403.pdf [Date Accessed: 10 July 2012].

2. American Marketing Association. (2007). Dictionary of Marketing Terms - Customer Satisfaction. Available from: http://www.marketingpower.com/mg-dictionary-view930.php.

3. Babakus, E., Bienstock, C.C. and Van Scotter, J.R. (2004). Linking perceived quality and customer satisfaction to store traffic and revenue growt, Decision Sciences, 35(4). Available from: http://www. blackwellsynergy.com/action/showPdf?submitPDF=Full+Text+PDF+\%28165+KB\%29\&doi=10.1111\%2Fj.15405915.2004.02671.x [Accessed: 2007-08-02].

4. Berman, B. (2011). Developing and implementing a customer service strategy, Retail Strategist, 2, pp. 10-16.

5. Berry, L.L. (2008). Delivering excellent service in retailing. Retailing Issues Letter, Arthur Anderson, College Station, TX.

6. Chang, C. (2006). When service fails: the role of the salesperson and a customer, Psychology and Marketing, 23(3), pp. 203-223. Available from: bin/fulltext?ID=112394878\&PLACEBO =IE.pdf\&mode=pdf [Accessed: 2012-08-01].

7. Darian, J.C. \& Cohen, J. (1995). Segmenting by consumer time shortage, Journal of Consumer Marketing, 12(1), pp. 32-44.

8. Darian, J.C., Tucci, L.A. \& Wiman, A.R. (2001). Perceived salesperson service attributes and retail patronage intentions, International Journal of Retail and Distribution Management, 18(5), pp. 205-213.

9. Gilbert, G.R. and Veloutsou, C. (2006). A cross-industry comparison of customer satisfaction, Journal of Services Marketing [online], 20(5), pp. 298-308. Available from: http://emeraldinsight.com/Insight/viewPDF.jsp? Filename $=$ html/Output/Published/EmeraldFullTextArticle/Pdf/0750200502.pdf [Accessed: 2007-07-10].

10. Kong, M. and Jorgaratnam. (2007). The influence of culture on perceptions of service employee behavior, Managing Service Quality [online], 17(3), pp. 275-297. Available from: http://www.emeraldinsight.com/ 
Insight/viewPDF.jsp?Filename=html/Output/Published/EmeraldFullTextArticle/Pdf/1080170303.pdf [Accessed: 2007-07-18].

11. Moore, M. \& Carpenter, J. (2006). The effect of price as a marketplace cue on retail patronage, Journal of Product and Brand Management, 2006, pp. 265-271.

12. Roig, J.C., Garcia, J.S., Tena, M.A.M. and Monzonis, J.L. (2006). Customer perceived value in banking services, International Journal of Bank Marketing [online], 24(5), pp. 266-283. Available from: http://www.emeraldinsight.com/Insight/TextArticle/Pdf/0320240501.pdf [Accessed: 2012-07-10].

13. Siu, N.Y.M. \& Cheung, J.T.H. (2001). A measure of retail service quality, Marketing Intelligence and Planning, pp. 88-96. 